\title{
Community structure of plankton in Aneuk Laot Lake Sabang Pulau Weh
}

\author{
Nurfadillah Nurfadillah ${ }^{1,3,4}$, Desrita Desrita $^{5^{*}}$, Irma Dewiyanti ${ }^{2,3,4}$, Sri Riska Rahayu ${ }^{1}$, Seri Maulidawati ${ }^{1}$, Siswani Sari $^{6}$, \\ Surikawati Surikawati ${ }^{6}$, and Indri Karina ${ }^{6}$ \\ ${ }^{1}$ Department of Aquaculture, Faculty of Marine and Fisheries Universitas Syiah Kuala, Banda Aceh, Indonesia \\ ${ }^{2}$ Department of Marine Science, Faculty of Marine and Fisheries Universitas Syiah Kuala, Banda Aceh \\ ${ }^{3}$ Laboratory of Marine Biology, Faculty of Marine and Fisheries, Universitas Syiah Kuala, Banda Aceh \\ ${ }^{4}$ Marine and Fishery Research Center, Universitas Syiah Kuala, Banda Aceh, Indonesia \\ ${ }^{5}$ Aquatic Resources Management Study Program, Agriculture Faculty, Universitas Sumatera Utara, Medan \\ ${ }^{6}$ Local environmental agency, Sabang
}

\begin{abstract}
The role of plankton as natural food affects the potential of fish in the waters. The structure of the plankton community in the Aneuk Laot Lake can provide an overview of the stability of these waters. This study aims to determine the plankton biomass and the structure of the plankton community of Aneuk Laot Lake Sabang. This research was conducted in September 2019 in the waters of Aneuk Laot Lake. Determination of observation stations using the stratified random sampling method, identification of plankton using the census method and analysis of chlorophyll-a using the Trichomatic method. The results showed that the plankton composition consisted of 27 phytoplankton and 4 zooplankton genera which were divided into Bacillarophyceae (36\%), Chlorophyceae (19\%), Cyanophyceae (16\%), Zygnematophyceae (10\%), Dinophyceae (3\%), Euglenophyceae (3\%) and Crustacean class (13\%). The abundance of plankton was $21,333 \mathrm{ind} / 1$, the most abundant type is Navicula sp. Diversity index value (2.97) is category high, eveness index (0.87) and low dominance index (0.07). Chlorophyll-a values ranged from 2.84 to $4.84 \mathrm{mg} / 1$ including the medium nutrient category. Aneuk Laot Lake has a high level of community stability with trophic status of mesotrophic-eutrophic.
\end{abstract}

\section{Introduction}

Aneuk Laot Lake is one of the lakes where is located in Sabang, Pulau Weh. The lake has produced clean water for communities of Sabang to fulfill their needs. Besides the sources of life, the lake also becomes a magnificent place for tourism, agriculture, farming, and fishing spot. Edyanto [1] said if the appearance of Aneuk Laot Lake in Sabang as the freshwater resources importantly for supporting plenty of community activities on the island. Referring to Yusifa et al [2] said Aneuk Laot Lake has not equipped the inlet and outlet of the water flow.

The exceeded exploitation of the resources is expected will corrupt the stability of the ecosystem in Anak Laot Lake. The high of community activities surrounding the waters tend to affect the contamination and damage of sustainability in the waters, with no exception of the plankton [3-5]. Plankton is one of the biotas that can be observed and measured for evaluating of quality of the waters [6-8]. Their appearance in the waters is an important function due to for delivering in food chain cycle. The phytoplankton has the ecology function as the primer producer in the food chain, thus making them as indicated the stability of the waters [ $9-$ 12].
The research regarding the waters Aneuk Laot Lake had been launched minimally. Some of the research that had been done namely the quality of the waters of Aneuk Laot Lake in Pulau Weh [1], the number quantity of waters of Aneuk Laot Lake[13], Morphometric the five of fish species which dominantly caught in Aneuk Laot Lake [14]. The chemical parameters and microbiology of Aneuk Laot Lake[15], and Investigation of shrinkage of water in Aneuk Laot Lake [2]. However, the structure of plankton in the waters of Aneuk Laot Lake has not been reported. One of the biotic components that can be the main factor in the waters is the plankton or the bioindicator.

Wirabumi et al [16] argued the existence of plankton particularly phytoplankton in the water importantly due to their characters as the autotroph which transformed the inorganic to be the organic through the photosynthesis process. This research had been conducted as the initial data for evaluating in managing the waters of Aneuk Laot Lake. This research was aimed for observing the abundance and structure of plankton in the waters of Aneuk Laot Lake Sabang, Pulau Weh.

\section{Methodology}

\footnotetext{
*Corresponding author: desrita@usu.ac.id
} 


\subsection{Sampling Area}

The research was conducted in Aneuk Laot Lake, Sabang, Province of Aceh. The sampling was tackled in September 2019. The map of research was portrayed in Figure 1.

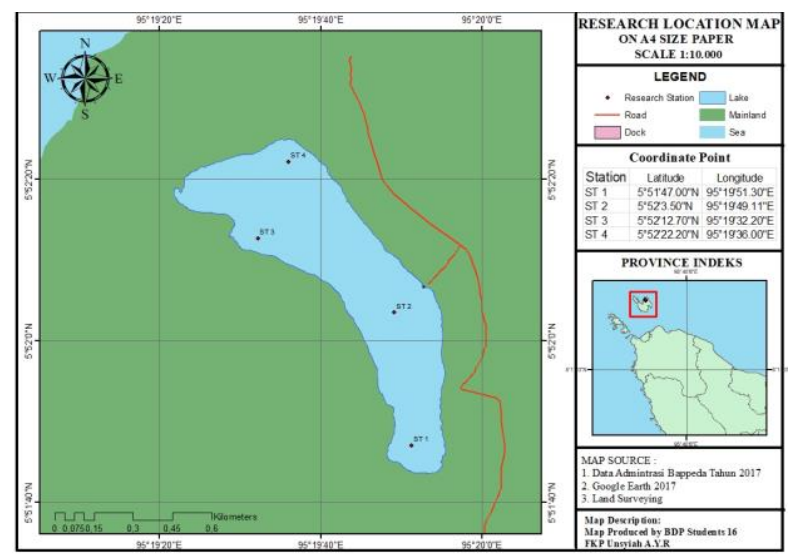

Fig. 1. Map of research

The determination of sampling spot was used the stratified random sampling. This research was divided into 4 (four) stations of observing. Namely, station 1 (The protected forest around of edge of the lake). Station 2 (The area of dock and tourism). Station 3 (The location which there was the intake of PDAM as the area for obtaining the clear water directly. Station 4 (the area of settlement, agriculture, and planting).

\subsection{Research procedure}

The sampling process had been conducted quantitatively through the filtering of plankton with equipment of the plankton net no. 25. The taking of water used the Van Dorn water sampler. The observing of the plankton used the census method. Identification of the plankton was addressed with the book of plankton [17], identifying marine diatoms and dinoflagellates [18], and identifying marine phytoplankton [18]. The parameters that had been measured comprised physic, chemical, and biology. Namely temperature, visibility, Dissolved Oxygen, $\mathrm{pH}$, nitrate-nitrogen $\left(\mathrm{NO}_{3}-\mathrm{N}\right)$, a total of phosphate dan chlorophyll-a.

\subsection{Data analysis}

\subsubsection{The abundance of phytoplankton}

The abundance of phytoplankton can be observed with the equation [19]:

$N=n \times \frac{a}{A} \times \frac{v}{v c} \times \frac{1}{V}$

Note: $\mathrm{N}=$ amount of plankton per litre (ind/l); $\mathrm{n}=$ amount of phytoplankton were identified (ind); $\mathrm{a}=$ wide of cover glass $\left(400 \mathrm{~mm}^{2}\right) ; \mathrm{A}=$ wide of far view (400 $\left.\mathrm{mm}^{2}\right) ; \mathrm{v}=$ volume of water concentrated $(50 \mathrm{ml}) ; \mathrm{vc}=$ volume of water dropped under of cover glass $(0.05 \mathrm{ml})$; $\mathrm{V}=$ volume of water filtered $(9 \mathrm{~L})$.

\subsubsection{Diversity of plankton}

The index that was used for evaluating the diversity of species-level was used the diversity index [20]

$$
H=-\sum_{i=0}^{s} \text { pi ln pi }
$$

Note: $\mathrm{H}^{\prime}=$ Index of species diversity, $\mathrm{pi}=$ probability of each part in overall $(\mathrm{ni} / \mathrm{N}), \mathrm{ni}=$ number of species individual to- $\mathrm{i} \mathrm{N}=$ number of the total individual.

\subsubsection{Evenness Index}

The evenness index of plankton is used for evaluating on how the huge similarity of the spread of individual each species in the communities. The evenness index is based on the equation [20]

$$
e=\frac{H^{\prime}}{\operatorname{Ln} S}
$$

Note: e $=$ Evenness Index, $\mathrm{H}^{\prime}=$ Diversity index, $\mathrm{S}=$ Number of species.

The range of evenness index between $0-1$. If the value of e close to 1 , the spreading of species evenly. If the value of e close to 0 indicated the spreading of species unequally, or there was the particular species dominantly [20].

\subsubsection{Dominance index}

The dominance index was obtained through the Simpson Index (Odum, 1971).

$$
C=\sum_{i=1}^{s}\left(n_{i} / N\right)^{2}
$$

Note: $\mathrm{C}=$ Simpson Dominancy Index, $\mathrm{ni}=$ number of species individual $\mathrm{i}, \mathrm{N}=$ number of total individual. The range of dominancy between $0-1$.

\section{Result and Discussion}

\subsection{Composition of species plankton}

Composition of plankton were discovered in the waters of Aneuk Laot Lake consisted of Bacillariophyceae $(36 \% ; 11$ genera), Cyanophyceae (16\%; 5 genera), Chlorophyceae $(19 \%$; 6 genera), Crustacea $(13 \% ; 4$ genera), Dinophyceae (3\%; 1 genera), Euglenophyceae (3\%; 1 genera), dan Zygnematophyceae $(10 \% ; 3$ genera). Based on the composition, Bacillariophyceae was the various dominantly found. It was related to Andriani et al [21] said if Bacillariophyceae was the species in generally was discovered in the waters due to adapted in their environment. The data composition of plankton in the waters of Aneuk Laot Lake is served in figure 2 . 


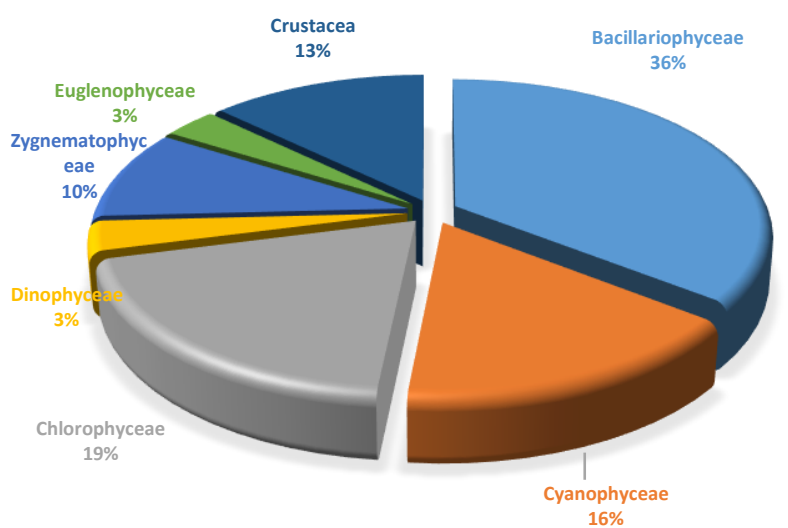

Fig. 2. Composition of plankton in Aneuk Laot Lake

Navicula sp is the biggest genus from Bacillariophyceae were found in the composition. The huge of Navicula sp. was depicted if this genus has the adapted level and high tolerance in the environment of waters such as $\mathrm{DO}, \mathrm{CO}_{2}$, visibility, and $\mathrm{pH}$ [22]. Martin and Fernandez [23] said Navicula sp. has the slimy stick which was used for patch tool on the substrate, both of in current waters and without the current entirely. Referring to Aryawati and Thoha [24] argued the Bacillariophyceae was cosmopolite which high adapted into the waters. The increase of phytoplankton diversity was influenced by the eutrophication process.

\subsection{Abundance of Plankton}

The abundance of plankton is the calculation amount of individual per volume of water (ind/l). The abundance of plankton in the waters of Aneuk Laot Lake can be found in Table 1.

Table 1. Abundance of Plankton in Aneuk Laot Lake

\begin{tabular}{|c|c|c|c|c|c|}
\hline \multirow{2}{*}{ No } & Plankton Species & \multicolumn{5}{c|}{ Station } \\
\cline { 3 - 6 } & & 1 & 2 & 3 & 4 \\
\hline \multicolumn{7}{|c|}{ Class Bacillariophyceae } \\
\hline 1 & Aulacoseira $s p$. & + & - & + & - \\
\hline 2 & Amphipleura sp & - & - & - & + \\
\hline 3 & Cocconeis sp. & + & - & - & + \\
\hline 4 & Cymbella sp & + & - & - & - \\
\hline 5 & Cyclotella sp. & - & - & - & + \\
\hline 6 & Fragilaria sp. & + & - & - & + \\
\hline 7 & Gomphonema sp. & - & - & - & + \\
\hline 8 & Navicula sp. & + & - & - & + \\
\hline 9 & Pinnularia sp. & + & - & - & - \\
\hline 10 & Synedra sp. & + & + & + & + \\
\hline 11 & Skeletonema $s p$ & + & - & - & - \\
\hline \multicolumn{7}{|c|}{ Class Cyanophyceae } \\
\hline 12 & Agmenellum $\mathrm{sp}$. & - & - & - & + \\
\hline 13 & Cuspidothrix $\mathrm{sp}$ & - & + & - & - \\
\hline 14 & Cuspidothrix $s p$ & + & - & - & - \\
\hline
\end{tabular}

\begin{tabular}{|c|c|c|c|c|c|}
\hline 15 & Merismopedia sp. & - & - & + & + \\
\hline 16 & Oscilatoria $\mathrm{sp}$ & - & - & - & + \\
\hline \multicolumn{6}{|c|}{ Class Chlorophyceae } \\
\hline 17 & Ankistrodesmus & - & - & - & + \\
\hline 18 & Closterium sp. & + & - & + & - \\
\hline 19 & Chlorella sp. & - & + & + & - \\
\hline 20 & Cosmarium sp. & - & + & - & + \\
\hline 21 & $\begin{array}{c}\text { Cylindrospermopsis } \\
s p .\end{array}$ & + & + & - & + \\
\hline 22 & Spirogyra sp & - & - & - & + \\
\hline \multicolumn{6}{|c|}{ Class Zygnematophyceae } \\
\hline 23 & Desmidium $s p$. & - & - & - & + \\
\hline 24 & Meugeotia sp. & - & - & + & + \\
\hline 25 & Zygnema sp. & + & - & + & - \\
\hline \multicolumn{6}{|c|}{ Class Dinophyceae } \\
\hline 26 & Ceratium $s p$ & + & - & - & + \\
\hline \multicolumn{6}{|c|}{ Class Eugleonaphyceae } \\
\hline 27 & Euglena $\mathrm{sp}$ & + & + & - & - \\
\hline \multicolumn{6}{|c|}{ Class Crustacea } \\
\hline 28 & Acartia $s p$ & - & - & - & + \\
\hline 29 & Calanus sp. & - & - & + & - \\
\hline 30 & Cyclops sp & + & - & - & + \\
\hline 31 & Oithona sp & - & - & - & + \\
\hline & $\begin{array}{l}\text { dance of Plankton } \\
\text { (ind/l) }\end{array}$ & $\begin{array}{c}11,11 \\
1\end{array}$ & $\begin{array}{c}1,66 \\
7\end{array}$ & $\begin{array}{c}2,88 \\
9\end{array}$ & $\begin{array}{c}5,55 \\
6\end{array}$ \\
\hline
\end{tabular}

The abundance of plankton was observed in four stations have an average of around $5.306 \mathrm{ind} / 1$. The highest phytoplankton was found in station $1(11,111$ ind/l) and the lowest in station $2(1,667 \mathrm{ind} / \mathrm{l})$. The abundance indicates of each station has a high nutrient and is suitable for plankton living. Based on Barus [25] the exceeding of plankton in the waters is closely related to the content of nutrients namely phosphate, nitrate, silicate, and other nutrients.

The highest abundance was in station 1 , wherein that station there was plenty of nutrients such as nitrate and phosphate which derived from the activities of the settlement around the lake. Linus and Irawati [26] said the huge concentration of nitrogen in the waters was caused by the waste of people's activities and also by the metabolism of sewage which sedimented in the bottom of waters. The highest abundance of Bacillariophyceae was expected due to the plenty of nitrogen. Besides that, Bacillariophyceae is one of diatom which tolerance through the temperature and can adapt in the extreme waters.

\subsection{Biology Index}

The structure of plankton communities is determined based on the several biology index, namely diversity index, evenness index, and dominancy. The diversity of plankton in the waters showed a value of around 2,97. Based on [20] if the diversity index was 
above 2,3 , indicated the waters were categorized as the middle stability. The evenness index of plankton showed averages 0,87 which illustrated the uniformity of plankton in the waters of Aneuk Laot Lake spread equally.

The dominancy of plankton in Aneuk Laot Lake was around 0,07 . The value indicated there were no plankton species dominantly in the location. Based on [27] argued if the range of dominancy index $0-0,50$, it showed the waters dominancy was low. Overall, the structure of plankton communities in Aneuk Laot Lake was categorized stably, where the diversity index in the middle value, the evenness index equally, and dominancy lowly. However, this condition can transform anytime based on the environment changes drastically. There are several factors that can change the plankton communities, namely sampling time, the appearance of nutrients, and climate change.

The quality of waters in all of the stations fluctuated and the range of value is still optimum for the living of plankton (Table 2).

Table 2. Parameters of water quality

\begin{tabular}{|c|c|c|c|c|c|}
\hline No. & Parameter & \multicolumn{4}{|c|}{ Station } \\
\cline { 3 - 6 } & & 1 & 2 & 3 & 4 \\
\hline 1 & $\begin{array}{c}\text { Temperature } \\
\left({ }^{\circ} \mathrm{C}\right)\end{array}$ & 29,44 & 29,42 & 30,37 & 30,36 \\
\hline 2 & Visibility (cm) & 99,2 & 128,5 & 82 & 75,5 \\
\hline 3 & Depth $(\mathrm{m})$ & 12 & 16,82 & 12,3 & 8,15 \\
\hline 4 & Current $(\mathrm{m} / \mathrm{s})$ & 0,02 & 0,31 & 0,18 & 0,36 \\
\hline 5 & $\mathrm{pH}$ & 7,8 & 8 & 8 & 8,2 \\
\hline 6 & $\begin{array}{c}\text { DO }(\mathrm{mg} / \mathrm{l}) \\
7\end{array}$ & 7,15 & 6,95 & 6,85 & 7,1 \\
\hline 8 & $\begin{array}{c}\text { Total of } \\
\text { phosphate } \\
(\mathrm{mg} / \mathrm{l})\end{array}$ & 0,28 & 0,43 & 0,38 & 0,36 \\
\hline 9 & $\begin{array}{c}\text { Total of } \\
\text { nitrogen }(\mathrm{mg} / \mathrm{l})\end{array}$ & 3,45 & 3,34 & 1,44 & 1,26 \\
\hline $\begin{array}{c}\text { Chlorophyll-a } \\
(\mu \mathrm{g} / \mathrm{l})\end{array}$ & 4,84 & 4,66 & 2,84 & 2,88 \\
\hline
\end{tabular}

The nutrient which affected the abundance of plankton is the total of phosphate and nitrogen. Phosphate and nitrogen are the nutrients that are absorbed by the plankton directly. Based on Indrayani et al [28] the P-totally in the waters depending on the particle which derived from the land into the waters caused by the erosion and the activities of humans and disturbed the living of plankton in the waters. Meanwhile, the relation of temperature and $\mathrm{pH}$ are the components that increased each other. The temperature experienced a slump along with the increasing deeply of waters, $\mathrm{pH}$, and $\mathrm{DO}$ as well.

\section{Conclusion}

The composition of plankton was discovered in Aneuk Laot Lake were 31 genera namely Bacillariophyceae 11 genera, Cyanophyceae 5 genera, Chlorophyceae 6 genera, Crustacea 4 genera, Dinophyceae 1 genera, Euglenophyceae 1 genera, and Zygnematophyceae 3 genera. The composition of plankton showed the class of Bacillariophyceae was dominantly in their species. The highest abundance was in station 1 around 11.111 ind/l. Overall, the structure of communities in Aneuk Laot Lake showed the diversity index $(2,97)$, the evenness index was equally $(0,87)$, and the dominancy index was low $(0,07)$.

\section{References}

1. C. B. H. Edyanto. Jurnal Teknik Lingkungan 1:115-124 (2006)

2. N.A. Yusifa, S. Yanto, Sairiyyah dan I. Muhammad. Jurnal Aceh Physic Social 8, 2: 47-54 (2019)

3. E. A. Tyas, S. Hutabarat, and C. Ain. Management of Aquatic Resources Journal (MAQUARES) 6, 2 (2018)

4. N. Nurfadillah, E. M. Adiwilaga, A. Damar J. Depik 1, 2: 93-98 (2012)

5. B. Suharto, L. Dewi, A. N. Mustaqiman, T.R.A.K. Marjo. Indonesian Journal of Urban and Environmental Technology 2, 2 (2019)

6. A. Muhtadi, Y. Yunasfi, F. F. Rais, N. Azmi, D. Ariska. Acta Aquatica: Aquatic Sciences Journal, 2, 2 (2015)

7. Z. Hasan, I. N. Syawalludin and W. Lili. Jurnal Akuatika 4, 1 (2013)

8. N. Nurfadillah, S. Tarina, E. Miswar, I Dewiyanti and S. Agustina (IOP Conference Series: Materials Science and Engineering, 567, 2019)

9. Gazali, Widiatmono, Rahadi and R. Wirosoedarmo. Jurnal Keteknikan Pertanian Tropis dan Biosistem 1, 2: 1-8 (2013)

10. A. Rahman and H. Satria. LIMNOTEK, 23 (1):1725 (2016)

11. F.F. Rais, D. Yunasfi and A. Muhtadi Aquacoastmarine. 9, 4:34-42 (2015)

12. E.P. Sagala. LIMNOTEK, 20 (2):151-158 (2013)

13. A. Riyad. Jurnal Teknik Lingkungan PTL-BPPT. 7, 2: $166-172$ (2006)

14. A. Khayra, Z.A. Muchlisin and M. A. Sarong. J. Depik, 5, 2: 57-66 (2016)

15. T. Widiyanto. Jurnal Limnotek Perairan Darat Tropis, 24, 2: 83-92 (2017)

16. P. Wirabumi, Sudarsono and Suhartini. Jurnal Prodi Biologi 6, 3: 174-184 (2017)

17. I.M. Shuthers and D. Rissik. Plankton. A Guide to Their Ecology and Monitoring for Water Quality (CSIRO Publish, Melbourne, 2009)

18. G. Hassle, E. Syvertsein, K. Streidinger, K. Tangen and C. Tomas. Marine diatom: identifying marine diatoms and dinoflagellates (Academic Press, 1996)

19. American Public Health Association [APHA]. Standard methods for the examination of water and wastewater. Amer. Publ. 17th Edition (New York Health Assosiation, 2005) 
20. E.P. Odum. Fundamental of Ecology Edisi III. Sounders College Publishing (Philadelphia, 1971)

21. S. Andriani, T.R. Setyawati, and I. Lovadi. Protobiont 4, 1 (2015)

22. T.R.S. Andriansyah and I. Lovadi. Protobiont 3, 1 (2014)

23. G. Martin and M.R. Fernandez. Diatoms as Indicators of Water Quality and Ecological Status: Sampling, Analysis and Some Ecological Remarks (InTech Europe, Croatia, 2012)

24. R. Aryawati and H. Thoha. Maspari Journal: Marine Science Research 2, 1: 89-94 (2011)

25. T.A. Barus. Jurnal Manusia dan Lingkungan 11, 2 : 64-72 (2004)

26. Y. Linus \& N. Irawati. Jurnal Manajemen Sumber Daya Perairan 2,1 (2016)

27. J.A. Ludwig, L. Quartet, J.F. Reynolds. Statistical ecology: a primer in methods and computing (Vol. 1) (John Wiley \& Sons, 1988)

28. E. Indrayani, K.H. Nitimulyo, S. Hadisusanto \& R. Rustadi. Jurnal Manusia dan Lingkungan, 22, 2 (2015) 